\title{
ЧИ Є ЧАС ЗВоРотНИМ?
}

\author{
Я.В. Шрамко
}

\section{1 Попередні зауваги щодо зворотності часу}

У філософській (і не лише філософській) літературі, присвяченій проблемі часу, правилом гарного тону вважається зазначення загадковості часу з обов'язковим покликанням на відповідне місце 14-ої глави 11-ої книги «Сповіді» св. Августина ${ }^{1}$. Відомий британський фізиктеоретик, піонер у галузі квантових обчислень і популяризатор науки Девід Дойч вважає, що «вся загадковість часу виникає з його основної властивості, а саме: теперішній момент, який ми називаємо „тепер“, не є стаціонарним, а постійно рухається в напрямку майбутнього» ${ }^{2}$. Проблема полягає в тому, що саме цей «рух», що зазвичай називається «плин часу», зовсім не є таким уже очевидним, як це може видатися на перший погляд. Дойч зауважує, що з точки зору класичної фізики поняття «плин часу» загалом е зайвим: «Жодна з фізичних теорій Ньютона не звертається до плину часу, як не звертається до нього і не сумісна з ним жодна з наступних фізичних теорій» ${ }^{3}$. Як добре відомо, фізичний фактор часу - не лише в перетвореннях Галілея, але й у перетвореннях Лоренца - позбавлений будь-яких характеристик, окрім суто кількісних, зокрема такої характеристики, як спрямованість.

${ }^{1}$ Див., напр.: Аксенов Г.П. Причина времени. - М. : Эдиториал УРСС, 2001.С. 19; Молчанов В.И. Время и сознание. Критика феноменологической философии. - М. : Высш. шк., 1998. - C.6; Deutsch D. The Fabric of Reality. - New York: Penguin Books, 1997. - P. 258; Price H. Time's Arrow and Archimedes' Point. - New York: Oxford University Press, 1996. - P. 3.

${ }^{2}$ Deutsch D. - Ibid.

${ }^{3}$ Deutsch D. - Op. cit. - P. 266. 
Між тим, у багатьох філософських концепціях саме спрямованість вважається найбільш фундаментальною специфічною властивістю часу, що визначає його якісну природу ${ }^{4}$. Знамените Лейбніцеве визначення часу як порядку послідовностей ${ }^{5}$ характеризує час винятково з якісного боку, на що звернув увагу С. Кларк у своєму відомому запереченні ${ }^{6}$. Зі свого боку, Г. Рейхенбах зауважує, що часовий порядок належить до направлених відношень і саме ця спрямованість й може бути виражена через різницю між минулим і майбутнім ${ }^{7}$.

З уявленням про спрямованість часу тісно пов'язане питання про його незворотність. Навіть якщо час стандартним чином протікає у якомусь одному (фіксованому) напрямку, що заважає цьому напрямку колись змінитися на протилежний? Із точки зору класичної фізики для цього не існує жодних перешкод фундаментального характеру. За зауваженням Л.І. Маневича, «рівняння руху Ньютона [...] залишаються інваріантними (незмінними) при формальній зміні ходу часу на протилежний. Із відсутності покликання на стрілу часу в рівняннях руху випливає зворотність їх рішень, тобто можливість отримати початковий стан із кінцевого» ${ }^{8}$. Те саме $\epsilon$ правильним і для класичної електродинаміки: «Рівняння Максвелла, подібно до рівнянь класичної механіки, не змінюються, якщо обернути напрям часу» ${ }^{9}$. Щодо класичної термодинаміки, то її друге начало стверджує незворотність процесу збільшення ентропії в ізольованих системах за умови відсутності в них будь-яких інших змін. Навіть якщо прийняти точку зору, що загалом світ утворює такого роду ізольовану термодинамічну систему, обертання часового порядку неминуче буде супроводжуватися згадуваними «іншими змінами», що як раз і відкриває принципову можливість для дії другого закону термодинаміки «у зворотному напрямку», тобто в напрямку зменшення ентропії.

У діалозі «Політик» Платон спробував обгрунтувати можливість «маятникового» розвитку світу, при якому «обертальний рух Всесві-

\footnotetext{
${ }^{4}$ Див., напр.: Reichenbach H. The Direction of Time. - Berkeley-Los Angeles : University of California Press, 1956.

${ }^{5}$ Див.: Лейбнии, Г.-В. Переписка с Кларком // Лейбниц Г.-В. Сочинения в 4-х тт. - М. : Мысль, 1982. - Т. 1. - С. 441.

${ }^{6}$ Див.: Там же. - С. 447.

${ }^{7}$ Reichenbach H. Op. cit. - P. 26-27.

${ }^{8}$ Маневич Л.И. Обратимость и стрела времени: между порядком и хаосом. Часть 1. Феноменология необратимости // Соросовский образовательный журнал. - 1997. - № 11. - С. 64 .

${ }^{9}$ Whitrow G.J. Natural Philosophy of Time. - New York: Oxford University Press, 1980. - P. 18.
} 
ту спрямований то в один бік, ... то в протилежний». Ситуація, що «супроводжує поворот Всесвіту, коли його рух повертається назад», зображується тут доволі виразно:

Вік живих істот, у якому кожна з них знаходилася, спочатку таким і залишався, і все, що було тоді смертельне, перестало старіти і виглядати старшим; навпаки, рух розпочався в протилежний бік, і все стало молодшим і більш ніжним: сиве волосся старців почорніло, щоки бородатих мужів наново стали гладкими, повертаючи кожного 3 них до колишньої квітучої пори; стрункими стали також і тіла змужнілих юнаків, з кожним днем і щоночі зменшувалися, допоки вони знову не стали новонародженими і не уподібнились їм як душею, так і тілом ${ }^{10}$.

Власне кажучи, як відзначав П. Зварт, саме таку картину слід мати на увазі при розгляді питання про зворотність часу:

Про зворотність часу зазвичай говорять у тому смислі, що все те, що вже сталося трапляється знов, але в зворотному напрямку. Усі процеси змінюють свій напрямок на протилежний, усі системи проходять крізь ті самі серії станів, лише в зворотній послідовності. Таким чином, усі наслідки й ознаки того, що трапилося, коли час ішов уперед, зникають при зворотному його протіканні, наче взагалі ніколи нічого й не відбувалося. Це може бути схожим на те, що ми бачимо, коли кіноплівку прокручують у зворотному напрямку: палаючі руїни стають будинками, розсипані на підлозі уламки скла, підстрибують угору $\mathrm{i}$, збираючись докупи, утворюють вазу тощо [...] Зворотність часу в такому розумінні може бути тільки загальною й універсальною; вона не може стосуватись лише частини Всесвіту, в такому разі було б неможливим, щоб стерлися всі сліди того, що трапилося. Тільки таке розуміння зворотності часу, як мені видається, є логічно можливим ${ }^{11}$.

Зауважимо, що при такому розумінні йдеться не про зворотність часу самого по собі, а про зворотність прочесів, що розвиваються в часі. Розглядаючи специфіку фізичних процесів у такому відношенні, Зварт згадує так звані «експерименти зі зворотності часу» (experiments in time reversal), що здійснювалися при вивченні гіперонів у 60их роках минулого століття ${ }^{12}$ задля встановлення часової інваріантності фізичних законів: «Якби було доведено, що часова інваріантність порушується хоча б у якомусь одному випадку, [...] то це означало $б$ неможливість зворотності часу» ${ }^{13}$. Характеризуючи ці експерименти, Зварт підкреслював, що насправді вони є не експериментами щодо

${ }^{10}$ Платон. Політик, 269c-271a.

${ }^{11}$ Zwart P.J. The flow of time // Synthese. - 1972. - № 24. - P. 155.

12 Див., напр.: Overseth O.E. Experiments in time reversal // Scientific American. 1969. - № 221. - P. 89-101.

${ }^{13}$ Zwart P.J. Op. cit. - P. 157. 
незворотності часу, але «експериментами зі зворотності елементарних процесів. Грунтуючись на їх результатах, можемо зробити висновок про можливість зворотності часу в принципі. Оскільки дотепер не було знайдено жодного прикладу незворотного елементарного процесу, ми робимо висновок, що на теперішній момент наші знання про природу не виключають а priori можливість зворотності часу» ${ }^{14}$.

У цьому випадку йдеться про спроби знайти приклад реального фізичного процесу, принципова незворотність якого могла би бути точно установлена. Пошуки такого процесу належать до компетенції фізиків-експериментаторів. Проте у більш широкому, загальнонауковому і навіть загальнофілософському плані можна поставити питання про можливість побудови моделі такого роду незворотного процесу без конкретної прив'язки до якихось специфічних фізичних умов. Ідеться про логічне моделювання процесів на зразок того, з яким ми маємо справу, наприклад, в апоріях Зенона. Якби нам вдалося сформулювати такого роду абстрактну математичну модель незворотного процесу, то тим самим проблема зворотності часу отримала б саме загальнофілософське розв'язання, яке мало б апріорний характер.

Метою цієї статті якраз і є обгрунтування такого апріорного загальнофілософського розв'язання вказаної проблеми. Проте, перш ніж приступити безпосередньо до їі аналізу, прояснимо деякі базисні поняття.

\section{2 Об'єкти, процеси і моменти}

Згідно з Людвігом Вітгенштейном, світ визначається фактами, які являють собою здійснені положення справ. Зі свого боку, положення справ виражають не що інше, як взаємозв'язок об'єктів (речей, предметів $)^{15}$. Іншими словами, співвідношення об'єктів утворюють положення справ і загалом - факти, у яких фіксується, що ті чи ті об'єкти мають деякі властивості, знаходяться між собою в різних відношеннях, або задіяні в певних прочесах.

Для цілей нашого аналізу особливо важлива остання обставина. Дещо видозмінюючи ще одне твердження Вітгенштейна ${ }^{16}$, можна сказати, що для об'єкта істотне не тільки те, що він може бути складовою частиною певного положення справ, а й те, що він може бути носієм

\footnotetext{
${ }^{14}$ Ibid.

${ }^{15}$ Вітгенштейн Л. Логіко-філософський трактат. $-1.11 ; 2 ; 2.01$.

16 Там же. -2.011.
} 
деякого процесу. По суті, будь-який процес являє собою послідовність станів деякого об'єкта, або кількох об'єктів, що виступають носіями цього процесу. Для стислості, будемо вести мову про стани самого процесу.

Процеси протікають у часі, час же складається з моментів. Поняття часового моменту є вихідним поняттям, що не підлягає визначенню, воно аналогічне поняттю точки в геометрії. Будь-який проміжок часу (часовий інтервал) являє собою деяку послідовність моментів, лінійно упорядкованих через відношення «раніше». Передбачається, що будьякі два моменти такої послідовності завжди можна розрізнити i, за необхідності, будь-який момент часу завжди можна зафіксувати (обчислити) з будь-яким необхідним ступенем точності.

Будемо вважати, по-перше, що процес однозначно визначається сукупністю своїх послідовних станів і, по-друге, що стан будь-якого процесу можна поставити у взаємно-однозначну відповідність до моменту з певного інтервалу часової послідовності. Тому про стани процесу можна еквівалентним чином говорити як про моменти його протікання. Процес може мати вихідний момент - початок процесу і кінцевий момент, яким цей процес завершується. Якщо процес не має початку та/або кінця, то такий процес називається нескінченним.

Відтворення процесу у зворотному напрямку являє собою сукупність його моментів, лінійно упорядкованих через відношення, яке є зворотним до відношення, за допомогою якого був упорядкований вихідний процес, причому для будь-яких двох моментів $a$ i $b$, що належать як вихідному процесу, так і його відтворенню у зворотному напрямку, виконується: $a R b \leftrightarrow b R^{-} a$, де $R$ i $R^{-}$суть взаємообернені відношення. Зокрема, взаємооберненими є відношення «раніше» $\mathrm{i}$ «пізніше».

Момент процесу, з якого розпочинається його відтворення у зворотному напрямку, виступає в ролі початкового моменту такого відтворення. Зворотне відтворення процесу завершується після досягнення початкового моменту вихідного процесу. Процес є зворотним, якщо і тільки якщо, починаючи з будь-якого заданого моменту цього процесу, його можна повністю відтворити у зворотному напрямку.

Час (в цілому) є зворотним, якщо і тільки якщо всі процеси, які тільки були, є або можуть бути, є зворотними. Відповідно, час як такий незворотний, якщо і тільки якщо існує хоча б один незворотний процес. Отже, для доказу незворотності часу достатньо показати, що можна змоделювати певний процес, який у принципі не може бути відтворений у зворотному напрямку. 


\section{3 Процес Irr i його незворотність}

Відтак у нас є все необхідне, аби побудувати конкретний процес, принципова незворотність якого може бути доведена строго логічним чином. Для моделювання цього процесу ми скористаємося задачеюголоволомкою, відомою в літературі під назвою «Собака Остіна» або в іншому її варіанті-«Троянська муха». Мартін Гарднер в одній зі своїх книг із цікавої математики викладає цю задачу таким чином:

Хлопчик, дівчинка і собака знаходяться в одній точці на прямій дорозі. Вони починають рухатися вперед; хлопчик зі швидкістю 4 милі на годину, дівчинка -3 милі на годину. У процесі їхнього руху собака безупинно бігає від хлопчика до дівчинки і назад зі швидкістю 10 миль на годину. Припустимо, що зміни напрямку їі руху на протилежний відбуваються миттєво. Де вона буде через годину і в який бік буде рухатися? ${ }^{17}$

Ця ж головоломка іноді характеризується як «парадокс», що отримав у літературі назву «Троянська муха»:

Ахіллес рухається зі швидкістю 8 миль на годину, а черепаха, на деякій відстані спереду - зі швидкістю 1 миля на годину. У той момент, коли Ахіллес наздоганяє черепаху, він також настигає муху, яка весь цей час літала між ними зі швидкістю 20 миль на годину і продовжує це робити й надалі. За годину Ахіллес знаходиться на 7 миль попереду черепахи. Де знаходиться муха? ${ }^{18}$

Сукупність проблем, пов'язаних із цією головоломкою, що надають їй характеру парадоксу, докладно обговорюється у главі 13 згадуваної книги М. Гарднера з посиланням, зокрема й на Уеслі Селмона ${ }^{19}$.

Ми не будемо розбирати тут ці проблеми, оскільки нас цікавить не сама задача по суті, а лише схема описаного в ній процесу, якою

${ }^{17}$ Gardner $M$. Wheels, Life and Other Mathematical Amusements. - New York: W.H. Freeman and Company, 1983. - P.34. Ця задача була вперше опублікована А.К. Остіном у січневому номері журналу «Mathematics Magazine» за 1971 р. Проблема полягає в тому, що згідно з запропонованою схемою розв'язання цієї задачі через годину собака може опинитися в будь-якій точці між хлопчиком і дівчинкою, а її морда може бути спрямована в будь-який бік. Ось як це обгрунтовує Гарднер: «Після того, як сплине година, помістіть собаку в довільну точку між хлопчиком i дівчинкою мордою в будь-який бік. Поверніть у часі рух хлопчика, дівчинки і собаки - i всі утрьох опиняться у вихідній точці в один і той же початковий момент» (Ibid. - P. 123). Зазначимо, що це міркування істотним чином спирається на припущення, що час є зворотним.

18 Див.: Clark M. Paradoxes from A to Z. - London and New York: Routledge.2002. - P. 200.

${ }^{19}$ Salmon W. Space, Time, and Motion: a Philosophical Introduction. - Minneapolis : University of Minnesota Press, 1980. 
ми й збираємося скористатися. В.І. Шалак в одній із дискусій у рамках проблемної групи «Логіка і філософія мови»- семінар IФ $\mathrm{PAH}^{20}$ запропонував певну спрощену модифікацію цієї схеми, яка дозволяє уникнути елементу невизначеності, що виникає в той момент, коли Ахіллес, черепаха і муха опиняються в одній точці. При цьому Шалак охарактеризував цю головоломку як «апорію» (утруднення), маючи на увазі її явну схожість із апоріями Зенона. В апорії Шалака замість рухомої черепахи фігурує нерухома непроникна стіна.

Ми використовуємо тут запропоновану Шалаком схему для точного опису певного незворотного в часі процесу, який позначаємо як Irr:

\section{Процес Irr.}

Два об'єкти, $a$ і $b$ (для «наочності» назвемо об'єкт $a$ «людиною», а об'єкт $b$ - «мухою»), знаходяться у вихідній точці $A$. На певній відстані від цієї точки розташована стіна (позначимо іiї $c$ ), яка непроникна як для людини, так і для мухи. Позначимо найближчу до точки $A$ точку на стіні як $B$. Тобто відрізок $[A, B]$ перпендикулярний прямій $c$. Весь процес починається з того, що людина і муха одночасно починають рух із точки $A$ до точки $B$, причому швидкість мухи удвічі вища, ніж швидкість людини. Стіна є обмежувачем руху мухи і людини, в тому смислі, що якщо, рухаючись вздовж відрізку $[A, B]$, муха або людина досягає стіни (в точці $B$ ), їхній рух спрямовується в протилежний від стіни бік до точки $A$. Людина також непроникна для мухи (і відповідно, є обмежувачем ㄲï руху, в тому смислі, що коли муха, рухаючись в інтервалі між людиною і стіною, потрапляє в точку, в якій знаходиться людина, то їі рух спрямовується до точки $B)$, за винятком того моменту, коли людина і муха разом (одночасно) перебувають у точці $B$. В останньому випадку рух як людини, так і мухи спрямовується до точки $A$. Завдання людини-досягнути точки $B$ i, змінивши напрям руху на протилежний, потрапити назад у точку $A$, після чого процес завершується ${ }^{21}$.

${ }^{20}$ Див.: http://www.facebook.com/groups/169180536448009/

${ }^{21}$ Важлива відмінність процесу Irr від апорії Шалака полягає в тому, що Irr не відповідає умові, що муха завжди має знаходитись в інтервалі між людиною і стіною (у Шалака людина завжди залишається непроникною для мухи). Чи є ця умова виконуваною, то інше окреме питання, що створює, на наш погляд, суть апорії Шалака. 
Важливо підкреслити, що тут йдеться не про реальний «фізичний» процес, а про певну математичну модель. Об'єкти $a$ і $b$ є тут навіть не матеріальними, а математичними точками: ми можемо знехтувати не лише їх розміром чи формою, але й їх масою; крім того, положення в просторі цих точок може збігатися ${ }^{22}$. Ми відволікаємося від усіх фізичних характеристик процесу Irr як від несуттєвих, наприклад, від того, що для зміни напрямку руху на протилежний фізичній мусі знадобилося б додаткове прискорення, і вважаємо, що упродовж усього процесу, аж до його завершення, швидкість обох об'єктів залишається незмінною, а також що зміна напрямку руху на протилежний як мухи, так і людини відбувається миттєво.

Нескладно побачити, що за умовами процесу $\mathrm{Irr}$, поки людина буде рухатися від точки $A$ до точки $B$, муха буде здійснювати «човникові» (коливальні) рухи від людини до стіни і назад, причому амплітуда цих рухів буде щоразу зменшуватися. Також зрозуміло, що в момент прибуття людини в точку $B$ муха також буде знаходитися в цій точці. Що ж відбудеться після того, як людина дістанеться стіни? Відповідь на це питання надає така лема:

Лема. У будъ-який момент, що йде за моментом прибуття людини $і$ мухи до стіни (у точиі В), муха буде знаходитися за межами відрізку шляху між стіною і людиною $i$, віддаляючись від стіни, рухатиметься прямолінійно в одному напрямку аж до завершення nрочесу.

Доведення. Як уже зазначено, людина потрапляє в точку $B$ одночасно з мухою. Згідно з умовами процесу, у цей (і тільки цей) момент людина не $є$ обмежувачем руху для мухи. Іншими словами, у цей момент людина і муха одночасно стартують як рівноправні об'єкти з точки $B$ у напрямку до точки $A$. Оскільки швидкість мухи удвічі вища за швидкість людини, то в будь-який момент, що йде за моментом досягнення ними точки $B$, муха буде знаходитися на відстані вдвічі більшій від стіни, ніж людина i, не маючи перед собою ніякого обмежувача руху, буде рухатися прямолінійно в одному напрямку, віддаляючись від стіни, аж до завершення процесу.

Лема доведена.

22 Як це прийнято у звичайних математичних задачах на рух: «Із пункту $A$ до пункту $B$ одночасно виїхали автомобіліст і велосипедист...»; «Два спортсмени одночасно починають рух із однієї точки... » тощо. 
B.I. Шалак звернув увагу на те, що доведення цієї леми, якщо воно правильне, може бути витлумачено як аргумент на користь незворотності часу. Ця обставина прояснюється у нижчевикладеній теоремі.

Теорема. Прочес Irr неможливо відтворити у зворотному напрямку, а саме: після досягнення людиною $і$ мухою (у ході такого зворотного відтворення) точки В будъ-який наступний стан процесу буде відрізнятися від будъ-якого стану вихідного прочесу Irr.

Доведення. Зворотне відтворення процесу Irr починається з моменту досягнення людиною точки $A$, що виступає як початковий момент такого зворотного відтворення. Згідно з лемою 1, муха в цей момент знаходиться на відстані $2 A$ від стіни. Зворотний процес триває без перешкод до того моменту, поки людина не досягне стіни у точці $B$. У той самий момент муха також прибуває до точки $B$. За умовами процесу, у цей момент людина не є обмежувачем руху мухи, і цей рух, так само як і рух людини спрямований до точки $A$. Значить, у будьякий наступний момент муха знову-таки буде знаходитися удвічі далі від стіни, ніж людина, тобто, вона вийде за межі інтервалу між стіною і людиною, у якому вона знаходилася у вихідному процесі. Отже, човниковий рух мухи між стіною і людиною буде неможливим, що означає неможливість загалом відтворення процесу $\operatorname{Irr}$ в зворотному напрямку.

Теорема доведена.

Отже, $B$ позначає своєрідну «точку неповернення» для всього процесу $\mathrm{Irr}$ - після досягнення цієї точки зворотне відтворення процесу стає неможливим.

\section{4 Висновок}

Незворотність часу можна тлумачити по-різному. У найбільш загальному розумінні незворотність означала б неможливість повернення будь-якого процесу в будь-якій точці його розвитку. Така тотальна незворотність, очевидно, не має місця, оскільки нескладно навести приклад фізичного процесу в якийсь момент його розвитку, подальший стан якого тотожний попередньому. Більше того, цілком можуть існувати локальні фізичні процеси, які після їх завершення можуть бути повністю відтворені у зворотному напрямку - так би мовити, від 
кінця і до початку. А значить, можна уявити собі окремі (обмежені) області, де всі процеси, в силу обставин, що склалися, якийсъ час розвиваються у зворотному напрямку.

Схожа «часткова зворотність», нехай навіть усіх процесів, ще не засвідчила б, однак, на користь зворотності часу як такого, оскільки зворотність часу в загальному розумінні стверджує здійсненність такого всезагального зворотного розвитку для будъ-яких сфер і тимчасових інтервалів довільної тривалості. Тому існування хоча б одного незворотного процесу є достатньою гарантією обов'язкового існування проміжків, де час не може бути поверненим назад.

Саме неможливість такої всезагальної зворотності часу загалом і встановлюється в цій статті. Ми розглянули конкретний приклад процесу, який не може бути повністю відтворений у зворотному напрямку за самими умовами своєї побудови. Центральною умовою такої незворотності виступає те, що один із об'єктів, що бере в ньому участь, у певний (виділений) момент втрачає деяку істотну властивість, котру цей об'єкт має в усі інші моменти процесу, у якому б напрямку він не розвивався. Йдеться про властивість об'єкта бути обмежувачем руху іншого об'єкта, що бере участь у процесі. Зазначена умова формулюється повністю симетричним чином, тому вона в незмінному стані повинна зберігати свою силу, як у вихідному процесі $\mathrm{Irr}$, так і при спробі його повернення.

Тією ж мірою, у якій сам процес Irr являє собою деяку абстрактну (математичну) модель, доведення теореми про його незворотність має суто логічний (навіть математичний) характер. У цьому доведенні не задіяні жодні фізичні властивості або відношення, які могли б бути притаманні реальним фізичним об'єктам. Це означає, що отриманий результат не залежить від тих чи тих фактичних особливостей побудови фізичного Всесвіту і виконується для всіх «можливих світів», а не тільки для кращого з них, у якому, якщо вірити Лейбніцу, всі ми маємо щастя жити.

Надійлла до редакиії 25 березня 2013 р. 